\title{
The Analysis of White House Occupant and Political Polarization in the United States
}

\author{
Oluwole Owoye ${ }^{a^{*},}$ Matthew Dabros ${ }^{b}$ \\ a Professor of Economics, Western Connecticut State University, United States. \\ ${ }^{\mathrm{b}}$ Assistant Professor of Political Science, Aurora University, United States \\ ${ }^{*}$ Corresponding author's email address: Owoyeo@wcsu.edu
}

\section{A R T I C L E I N F O}

Received: 23-03-2017

Accepted: 12-04-2017

Available online: 13-05-2017

Keywords:

Congressional productivity;

Dominant strategy;

Partisanship;

Political polarization;

White House Occupant.

JEL Classification:

D71; D73; D74; H11; H73; H77.

\begin{abstract}
A B S T R A C T
This paper examines a previously unidentified causal factor - White House Occupant (WHO) or President of the United States (POTUS) - in political polarization and then investigates its impact on legislative productivity and the aggregate economy. Objective pundits would agree that the United States has entered a new phase of "toxically pandemic political polarization" because Congressional Republicans had racial resentment of Obama and they did everything to obstruct his policy agenda; and now, in retaliation and on policy issues, Democrats resent Trump. In view of the changing American electorate, we consider WHO's or POTUS's race or gender or perceived religious affiliation or policy positions to be an important causal factor that will contribute to extreme political polarization in the foreseeable future. This is problematic because a WHO could take advantage of a highly polarized and dysfunctional Congress to undermine the democratic principles that American cherish if Congressional members of his/her majority party are unwilling to provide the constitutional checks and balances. We model how political polarization will in turn depress economic growth. In addition to introducing a novel element to the ongoing research on the consequences of political polarization, this paper contributes to the broader literature by asserting that a WHO or POTUS is one of the determinants of political polarization and Congressional productivity; and that the remarkable contraction in Congressional productivity during Obama's presidency, which we found to be statistically and significantly different from the other three two-term presidents who served in the past four decades supported this assertion.
\end{abstract}

This is an open access article under the terms of the Creative Commons Attribution License 4.0, which allows use, distribution and reproduction in any medium, provided the original work is properly cited.

\section{Introduction}

Over the past several years, political analysts have noted the low productivity rates of the United States Congress, prompting one reporter to ask, "If lawmakers don't make laws, are they really lawmakers?" (James 2013). Democrat and Republican legislators commonly hoist the blame for Congressional inactivity on each other shoulder's, pointing to major partisan differences between them and citing the opposite party's unwillingness to compromise. Judging by some members' rhetoric, it often appears that legislators perceive bipartisanship as the betrayal of ideological principles, and in truth, the partisan division has grown large in the post-WWII period, especially during the eight years of Obama's presidency. Given the conditions surrounding the 2016 presidential election, we foresee no end to the political polarization in Congress and the general electorate. In their review of 
the literature, Barber and McCarty (2013) group potential explanations for increases in polarization into external and internal changes in Congressional environments. With respect to external explanations, Barber and McCarty (2013) and many scholars point to a polarized electorate, Southern realignment, gerrymandering, primary elections, economic inequality, money in politics, and the media environment; and with respect to internal explanations, they point to the rule changes, majority-party agenda control, party pressures, teamsmanship, and the breakdown of bipartisan norms. ${ }^{1}$

This paper contributes to the literature by filling one of the research gaps with respect to political polarization in the United States. In doing so, we provide a new dimension with which researchers can now examine political polarization. Until now, studies have not considered or identified the White House Occupant (WHO) or the President of the United States (POTUS) as a causal factor in political polarization. ${ }^{2}$ As a contribution to the ongoing debate about political polarization, our study identifies a third factor that exacerbated political polarization during the eight years of Obama's presidency: racial resentment or discrimination against WHO or POTUS by Congressional Republicans. Now, we expect Congressional Democrats to take retaliatory stance against the Trump's presidency and Congressional Republicans on policy issues/positions and not racial resentment or discrimination; therefore, this tit-for-tat policy posture will exacerbate political polarization into the foreseeable future.

In this regard, this study complements other studies such as those by Tope et al. (2014), Hughey (2012), BonillaSilva (2010), and Huddy and Feldman (2009) that examine the racial attitudes related to the dubious beliefs about the first African-American President of the United States. These studies suggest that both overt and symbolic racial sentiments, stereotypes and resentment continue to influence contemporary politics [also see Sears and Henry (2005)]. Studies postulate that the election of President Obama paved the way for the observed national and Congressional racial resentment and that this once again exposed the racial resentment that encouraged Southern Whites to vote for Republican candidates since the passage of the Civil Rights Act of 1964 and the Voting Right Act of 1965 (Hare and Poole, 2014, pp. 415-416). We assert that these social-cultural racial issues, at least partially, explained why some individuals, especially Republicans, labeled Obama as "secretly a Muslim and/or a noncitizen" [see Tope et al. (2014, p. 451)], "a liar", "an arrogant racist", "lazy", "lawless", or behaving like an "emperor." These vitriols against Obama as the WHO or POTUS based on racial resentment basically heightened political polarization, which had adverse effect on Congressional productivity during the presidency of Obama. Our examination and statistical tests of data on Congressional legislation over the past four decades showed and confirmed that Congressional productivity was at its lowest during Obama's two-term presidency.

To point out the impact of a WHO on political polarization, we incorporate the concept of presidential discrimination to highlight the partisan animus against a WHO. We define presidential discrimination/resentment or partisan animosity towards a WHO as the unfavorable treatment by the opposition party solely on the basis of race or gender identity, perceived religious affiliation, and policy positions, or as the willingness of the opposition party to resist a WHO's policies, even when these were the opposition party's policy positions that a WHO adopted. Our concept of presidential racial discrimination or resentment is deeply rooted in the pioneering work of Gary Becker (1957). ${ }^{3}$ We argue that just as the acts of gender and racial discrimination occur in different private sectors of the economy, its occurrence at the Congressional level of government in recent years has been overlooked. We strongly argue that presidential discrimination intensified partisanship and political polarization in the Congress during Obama's presidency.

Based on the changing demographics of the American electorate and the increasing probability that a future WHO may be a woman ${ }^{4}$ or a Hispanic-American or a Jewish-American or White-American who may not be acceptable to the opposite party, we postulate that presidential resentment will take on added relevance in the next four or eight years of Trump's presidency, with either positive ${ }^{5}$ or negative consequences in terms of Congressional productivity and economic growth. This paper is therefore an attempt to provide a new dimension to the scholarly debate about political polarization so that studies can explore it within the context of a collective model of racial discrimination against a WHO or within a retaliatory strategy profile on policy positions. In essence, this paper

\footnotetext{
${ }^{1}$ For a detailed discussion of the external and internal explanations of political polarization in Congress, see Barber and McCarty (2013), pp. 19-53.

2 Throughout this paper, White House Occupant (WHO) is the same as the President of the United States (POTUS).

${ }^{3}$ According to Gary Becker (1957), discrimination could come in the form of employers against certain employees, employees against other employees of a different race or gender, consumers and governments, market, and discrimination against nonwhite. For other contributors to the subject, see Stiglitz (1973) and Darity, Jr. (1989).

${ }^{4}$ It is important to note that the first woman presidential candidate ever nominated by either party in the 2016 election won the national popular votes but lost the Electoral College votes.

${ }^{5}$ The legislative outcomes could be positive because Republicans now have total control of the White House and Congress; therefore, they have the advantage, if united, in passing many legislative bills.
} 
argues that the perceived fear of the first two-term African-American President deepened political polarization within the general electorate and Congress more than anyone imagined even though some analysts may disagree with this argument. ${ }^{6}$ Many scholars argue that the bipartisan coalitions of the 1940 s through the 1960 s morphed into party-line voting and polarization since the mid-1970s (Barber and McCarty, 2013), and we model how this may ultimately have a negative impact on economic growth.

This paper is organized as follows. In section 2, we provide a brief survey of the relevant literature on political polarization. In Section 3, we examine the trends in Congressional polarization and discuss how this affected legislative productivity. In Section 4, we provide a game theoretical model in which we consider discrimination against a WHO and whether or not a WHO's political capital matters in trying to sway Congress to support policy agenda, show how this contributed to partisan political polarization, and then examine the consequences on Congressional productivity and on economic growth. Section 5 is devoted to results and discussion along with lessons learned from the outcomes of the recent election. In doing this, we provide tentative answers to some pertinent questions: How can the system curtail political polarization such that the vitriols in Congress is eliminated or what can the system do to minimize the election of extremely partisan political candidates who run for Congress with obstruction as the overarching objective and with no significant legislative contributions made while in office, but continued to champion "conflict extension"? ${ }^{7}$ How do we curtail "conflict extension" and the apparent "toxically pandemic political polarization" if a WHO realizes the political disarray and uses his/her political capital for political reprisals with authoritarian propensities when both the Congress and the electorate disagree with his/her policy positions? What did we learn from the outcomes of the 2016 election that produced the 45th WHO and the Republican majority in Congress?

\section{A survey of the literature}

Researchers have exploited a number of methodologies to examine political polarization, and have identified different causal factors that are considered to be external and internal.8 Barber and McCarty (2013, pp. 23-35) provided an encyclopedic review of these studies. In Table 1, we provide succinct summaries of those studies that identified a polarized electorate, gerrymandering, primary elections, economic inequality, money in politics, and media environment as the external factors. Similarly, in Table 2, we provide summaries of those studies that identified rule changes, majority-party agenda control, party pressures, teamsmanship, and the breakdown of bipartisan norms as the causal internal factors.

A perusal of Tables 1 and 2, which summarize these explanations, reveal an apparent consensus among a majority of these studies in terms of the two most important causal factors over the past 40 years: a polarized electorate and money in politics. Arguably, a polarized electorate has translated into a partisan and politically polarized Congress because legislators reflect the political ideologies of their constituents; while money in politics continues to corrupt the system thus the corrosive political environment at all levels of government. A further examination reveals that studies as far back as the 1960s and 1970s focused more on the external causal factors responsible for the increased partisanship and polarization, and that some of these factors are more recent; for instance, party primaries, economic inequalities, and the media environment have received significant attention since the early 2000s.

Table 1: Summary of the literature on the external causal factors of partisanship and political polarization

\begin{tabular}{|c|c|c|c|}
\hline Causal Fact & & Explanations & Author(s) \\
\hline $\begin{array}{l}\text { 1. A } \quad \mathrm{A} \\
\text { Electorate }\end{array}$ & Polarized & $\begin{array}{l}\text { Legislators' behaviors reflect the } \\
\text { preferences of their constituents, } \\
\text { who are themselves polarized. }\end{array}$ & $\begin{array}{l}\text { McClosky etal.(1960), Bartels (2000), Layman } \\
\text { and Casey (2002), Sunstein (2002), Klinkner } \\
\text { (2004), Fiorina et al. (2005), McCarty et al. } \\
\text { (2006), Carsey and Layman (2006), Clinton } \\
\text { (2006), Ansolabehere etal.(2006), Fiorina and } \\
\text { Abrams (2008), Levendusky et al. (2008), } \\
\text { Levendusky (2009), Gelman (2009), Bishop }\end{array}$ \\
\hline
\end{tabular}

${ }^{6}$ Many disagree because they thought America finally closed the chapter with respect to its annals of bigotry and racial discrimination with the election of the first African-American as the President of the United States, but could not imagine or estimate: (a) the negative political reactions to Obama by the heavily polarized electorate and some Congressional Republicans who continued to view him as "secretly a Muslim and/or a noncitizen," (b) the fear that Obama's policies will favor AfricanAmericans, and (c) that Obama will worsen race relations. For more detailed empirical findings on the above mentioned reactions to Obama, see Tope etal. (2014, pp. 460-461) and Hughey (2012).

7 For more detailed discussion on party polarization and "conflict extension," see the studies by Layman and Carsey (2002), Layman et al. (2010), and Hare and Poole (2014).

${ }^{8}$ See Rohde (1991), Sinclair (2006), Hacker and Pierson (2006), Mann and Ornstein (2012), McCarty, Poole, and Rosenthal (1997, 2006), Poole (2007), and Lee (2009). 


\begin{abstract}
2. Gerrymandering State legislatures draw congressional districts that enable Congressmen and women to remain in office rather than compete for votes at the political center.
\end{abstract}

3. Primary Elections.

Movement from closed partisan primaries to open primaries in order to allow the participation of independents.

4. Economic Inequality Increased economic inequality is hypothesized to be highly correlated with political polarization.

5. Money in Politics

6. Media Environment Changes in the media environment of politics, specifically since the Watergate scandal, may also have had an important role in polarization.
(2009), Abramowitz (2010), Bafumi and Herron (2010), Layman et al. (2010), Lenz (2012), Shaw (2012), and Fiorina (2013).

Tufte (1973), Carson et al. (2007), Theriault (2008), McCarty et al. (2006, 2009).

Kaufman et al. (2003), McCarty et al. (2006), Hirano et al. (2010), Bullock and Clinton (2011), Masket et al. (2013).

Brewer et al. (2002), Piketty and Saez (2003), McCarty et al. (2006), Bartels (2008), Gelman (2009), Garand (2010), and Gilens (2012).

Hall and Wayman (1990), Jacobson (1990), Baron (1994), Smith (1995), Ansolabehere et al. (2003), Moon (2004), McCarty etal. (2006), Ensley (2009), Bafumi and Herron (2010), Stone and Simas (2010), Lessig (2011), Bonica (2013), and Barber (2013).

Groseclose and Milyo (2005), Gentzkow and Shapiro (2006), Zeliner (2006), DellaVigna and Kaplan (2007), Prior (2007), Gerber et al. (2009), and Snyder and Stromberg (2010).

Table 2: Summary of the literature on the internal causal factors of partisanship and political polarization

\begin{tabular}{|c|c|c|}
\hline Causal Factors & Explanations & Authors \\
\hline 1. Rule Changes & $\begin{array}{l}\text { Procedural changes which made it easier for } \\
\text { amendments to be proposed when considering } \\
\text { legislation tend to force the opposition party to cast } \\
\text { unpopular votes in order to move on with the main } \\
\text { piece of legislation, thus aggravating the partisan } \\
\text { differences and ultimately polarization. }\end{array}$ & $\begin{array}{l}\text { Roberts and Smith (2003), } \\
\text { Roberts (2007), Theriault } \\
\text { (2008a), and Shor and } \\
\text { McCarty (2011). }\end{array}$ \\
\hline $\begin{array}{l}\text { 2. Majority-Party } \\
\text { Agenda Control }\end{array}$ & $\begin{array}{l}\text { Leaders of the majority party in both the House and the } \\
\text { Senate have used their power to control the legislative } \\
\text { agenda in order to build party loyalty, thus leading to } \\
\text { party-line votes and increased polarization. }\end{array}$ & $\begin{array}{l}\text { Rohde (1991), Aldrich } \\
\text { (1995), Cox and McCubbins } \\
\text { (2005), and McCarty et al. } \\
\text { (2006). }\end{array}$ \\
\hline 3. Party Pressures & $\begin{array}{l}\text { Given the power vested in the party leaders in the House } \\
\text { and the Senate, they are able to apply stronger } \\
\text { pressures on members to vote party lines, either by } \\
\text { coercion or by offering rewards in terms of committee } \\
\text { membership. }\end{array}$ & $\begin{array}{l}\text { Rohde (1991), Snyder and } \\
\text { Groseclose (2000), McCarty } \\
\text { et al. (2001), Theriault } \\
(2008 b) \text {, and Edwards } \\
(2012) \text {. }\end{array}$ \\
\hline 4. Teamsmanship & $\begin{array}{l}\text { As the two parties become more competitive in seeking } \\
\text { control of national agenda, the desire to differentiate } \\
\text { one party from the other has forced both parties to } \\
\text { engage in strategies of confrontation in order to } \\
\text { highlight their partisan differences. }\end{array}$ & $\begin{array}{l}\text { Gilmour 1995), Groseclose } \\
\text { and McCarty (2001), and Lee } \\
\text { (2009). }\end{array}$ \\
\hline $\begin{array}{l}\text { 5. The Breakdown of } \\
\text { Partisan Norms }\end{array}$ & $\begin{array}{l}\text { These days, members of Congress spend more time on } \\
\text { fundraising in their districts and less time in } \\
\text { Washington, thus their inability to build bipartisan } \\
\text { coalition, trust, and civility. }\end{array}$ & Eilperin (2007) \\
\hline
\end{tabular}




\section{Trends in and potential consequences of political polarization}

Scholars have been debating the issue of increasing partisanship and political polarization since the 1960 s. The basic finding of this literature is that both parties' ideologies have become more extreme over the past 40 years. Republicans in the House and Senate have moved significantly farther to the right of the political spectrum while Democrats have moved to the left; and many studies assert that this shift has been more pronounced for Republicans (Hacker and Pierson 2006; Mann and Orenstein 2012). According to Hare et al. (2012), the "rightward shift is especially dramatic among House Republicans, from an ideology score mean of 0.22 in 1975 to 0.67 in 2012."

Given the level of skepticism in our political discourse, one debatable empirical issue is whether or not the increase in partisanship and political polarization affects the ability of Congress to enact bills into laws. As Barber and McCarty (2013, p. 38) point out, there has not been much work on this issue, and that the findings to date are thus more suggestive than definitive but are however illuminating. According to McCarty (2007), "At the upper end of the range of estimates, Congress produced 166\% more legislation in the least-polarized Congressional term than in the most-polarized term. Even at the lower range of his estimates, there is still a large - $60 \%-$ difference in legislative output" (Barber and McCarty, 2013, p. 38), and that legislative productivity measured by the number of bills enacted into laws per Congress has decreased in the post-WWII period, largely due to the increases in political polarization.

Some scholars point out that the Congressional productivity was already declining before the election of President Obama, and that given the increasing technical complexity ${ }^{9}$ of the legislative process and laws, the decline in productivity during the eight years of Obama's presidency may be unrelated. While we acknowledge that this is a valid argument, but at the same time, one cannot dismiss the indisputable observable fact that Obama's presidency became the accelerometer of the rate of Congressional productivity decline. It was well known nationwide that Congressional Republicans were determined to obstruct Obama's legislative agenda at any cost, and this was the mission they accomplished. For example, the Senate Republicans did not allow Obama's nominee for the United States Supreme Court to have a Senate hearing in 2016.

To highlight the magnitude of the decline in Congressional productivity during the Obama's presidency, we provide the data evidence for different presidential administrations over the past 40 years in Table 3. One can surmise that the bipartisanship that existed during Reagan's second term led to a remarkable improvement in Congressional productivity; therefore, one can attribute this improvement to fact that the Congress was leastpolarized because the Speaker of the House (Tip O'Neill - a Democrat) and Reagan (a Republican WHO) formed the necessary working bipartisan coalition in the mid-1980s. Even though the level of Congressional productivity was down in both Bill Clinton's and George Bush's first term, each experienced a noticeable turnaround in his second term. During Obama's two-term presidency, Congressional productivity declined by 24.58 percent and 33.72 percent, respectively, when compared to George Bush's.

Table 3: Congressional productivity: Laws enacted

\begin{tabular}{lrr}
\hline Presidents & First Term & Second Term \\
\hline Richard Nixon/Gerald Ford & 1,501 & - \\
Jimmy Carter & 1,540 & 1,448 \\
Ronald Reagan & 1,206 & \\
H.W. Bush & 1,275 & 1,008 \\
Bill Clinton & 810 & 943 \\
George W. Bush & 887 & $625 \neq$ \\
Barack Obama & 669 & \\
\hline
\end{tabular}

Source: Congressional Record, Resume of Congressional Activity, available at www.senate.gov. and/or Historical Statistics about Legislation in the U.S, Congress, Statistics and Historical Comparison, available at https://www.govtrac.us. $\ddagger$ As of January 3, 2017.

As we can see in Table 3, the previous three two-term Presidents (Reagan, Clinton, and Bush) experienced increased legislative productivity during their second term. Obama's second term experienced significantly fewer laws enacted than his other three predecessors who also served two terms as a WHO. The question is whether or not the low Congressional productivity during Obama's presidency could be attributed to his perceived "laziness" or to the persistent obstructions by Congressional Republicans or Obama's inability to use his political capital to form a workable coalition with John Boehner (Speaker of the House) and his successor Paul Ryan.

\footnotetext{
${ }^{9}$ We are grateful to the discussant of an earlier version of this paper, at the $78^{\text {th }}$ International Atlantic Economic Conference in Savannah, Georgia, for pointing our attention to the technical complexity in legislations that could explain the declining Congressional productivity pre-Obama's presidency.
} 
We are aware that if there are no statistical tests to validate the observed differences in Congressional productivity reported in Table 3, the visual data evidence may be subject to dispute. To validate the data that Congressional productivity during Obama's presidency differed significantly from the other presidents that also served twoterms over the past four decades, we test three null hypotheses versus their alternative or research hypotheses given as:

$$
\begin{aligned}
& H_{1}:\left.\mu\right|_{\text {Obama }} \geq\left.\mu\right|_{\text {G.W. Bush versus }} H_{\mathrm{A} 1}:\left.\mu\right|_{\text {Obama }}<\left.\mu\right|_{\text {G.W.Bush }} \\
& H_{2}:\left.\mu\right|_{\text {Obama }} \geq\left.\mu\right|_{\text {Clinton versus } H_{\mathrm{A} 2}:\left.\mu\right|_{\text {Obama }}<\left.\mu\right|_{\text {Clinton }}} \\
& H_{3}:\left.\mu\right|_{\text {Obama }} \geq\left.\mu\right|_{\text {Reagan }} \text { versus } H_{\mathrm{A} 3}:\left.\mu\right|_{\text {Obama }}<\left.\mu\right|_{\text {Reagan }}
\end{aligned}
$$

where $H_{1}, H_{2}, H_{3}$; and $H_{\mathrm{A} 1}, H_{\mathrm{A} 2}$, and $H_{\mathrm{A} 3}$ are the null and research hypotheses, respectively, and $\mu$ is the measure of the averages of Congressional productivity during the presidencies of Obama, G.W. Bush, Clinton, and Reagan. In each case given by equations (i) - (iii), we reject the null hypothesis if the value of the computed $t$-values are greater than the $t$-table values in a one-tailed test at 99 percent and 95 percent confidence levels (that is, $\alpha=0.01$ and 0.05 ). The estimated results are summarized below. Based on the computed $t$-values reported in the last column in the table, we reject the null hypotheses in favor of the alternative or research hypotheses that Congressional productivity during Obama's presidency was less than the other three two-term presidents.

\begin{tabular}{|c|c|c|c|c|c|c|c|}
\hline \multirow[t]{2}{*}{ Congr. Sessions } & \multicolumn{6}{|c|}{ Mean } & \multirow[t]{2}{*}{ Calculated $t$-values } \\
\hline & Presidents & Min. & Mean & Max. & Diff. & Comparison & \\
\hline 4 & Obama & 284 & 323.5 & 385 & -------- & ----------- & ------- \\
\hline 4 & G.W. Bush & 383 & 457.5 & 504 & -134.0 & Obama vs. G.W. Bush & $3.86^{*}$ \\
\hline 4 & Clinton & 337 & 454.5 & 604 & -131.0 & Obama vs. Clinton & $3.14^{* *}$ \\
\hline 4 & Reagan & 529 & 663.5 & 761 & -340.0 & Obama vs. Reagan & $6.35^{*}$ \\
\hline
\end{tabular}

Estimated statistical results of the tests of differences in congressional productivity: Obama compared with three two-term presidents

Other research scholars and political experts attribute the low Congressional productivity during Obama's presidency to the ever widening political ideologies between both parties, and more so, Obama was a WHO perceived to embody the social-cultural racial issues of the 1960s and 1970s that sparked the Southern realignment. According to Hare et al. (2012), the Democrats' movement to the left appeared to be driven by their implicit desire to incorporate identity politics into their strategic calculus, and that "with time, emphasis shifted to issues that centered on race, gender, ethnicity, or sexual preference", and that these issues have also contributed to polarization. In a recent study based on a sample of 1,595 White respondents, Tope et al. (2014) examined "the relationship between Whites' racial attitudes and their likelihood of othering Barack Obama." In their study, they analyzed two questions with respect to Obama's citizenship and religious affiliation; and they found that both overt and symbolic racial resentment "continue to play a major role in politics." Interpretatively, the "Othering of Obama" was essentially presidential discrimination based on racial resentment and misperceived religious affiliation, which further exacerbated extreme partisanship and political polarization, and this partially explained the decline in Congressional productivity during Obama's two-term presidency.

\section{A theoretical model and the economic consequences of political polarization}

Given the causal factors we discussed earlier, one cannot ignore the possibility that political polarization exacerbated because of Republicans' perception of Obama's presidency: from Senator Mitch McConnell's desire to make Obama a one-term president through the obstructions of Obama's legislative proposals to Donald Trump's birther movement since 2011, which became the foundation of his candidacy for president. Taking executive-legislative relations during the Obama's presidency as a case in point, some observers are of the opinion that presidential discrimination or partisan animosity manifested during Obama's administration, and that Obama's inability to expend his political capital led to his use of executive actions and orders. Many pundits concur with these opinions. For example, as early as January 2009, former President Jimmy Carter expressed his belief that "an overwhelming portion of the intensely demonstrated animosity toward President Barack Obama ... is based on the fact that he is a black man, that he's African-American." (CNN 2009). In an editorial in January 2012, Andrew Rosenthal of the New York Times declared that "There has been a racist undertone to many of the Republicans' attacks levied against President Obama for the last three years...You can detect this undertone in the level of disrespect for this president that would be unthinkable were he not African-American." These are two of many observations made by political analysts. Whether these actions and comments accurately reflect the attitudes of some Republicans is clearly debatable.

Our point is simply that to the extent that such attitudes colored legislative perceptions of Obama as the past WHO, widening political and electorate polarization was instinctively obvious; and this may explain why Democrats are 
ready to reciprocate or retaliate against Trump whose ascension into the presidency along with his policy pronouncements on national and foreign policy issues has further polarized Congress, the electorate, and perhaps the international community.

To highlight the possibility of what we term "toxically pandemic political polarization" if the opposite party discriminates against a WHO, we draw on Becker's (1957) The Economics of Discrimination. Since the publication of this seminal work, numerous studies have explored the economics of discrimination within the frameworks of the competitive and collective models. Since our analysis focuses on two political parties in a democratic system of government, we employ the collective model, which examines the behavior of different groups acting against each other. We argue that partisan presidential discrimination exists when the opposite party controls the legislative branch of government, and members of the opposite party in both chambers are averse to endorsing the legislative proposals introduced on behalf of a WHO and/or his party, even though these may have been the same legislative proposals of the opposition party that WHO adopted and embraced in order to gain the support of the opposition party. ${ }^{10}$

\subsection{WHO-based model of discrimination: A game theoretic approach}

In order to comprehend the underlying factors with respect to discrimination or animosity against a WHO, we show the political interactions between Democrats (DEM) and Republicans (REP) in Congress using a game theoretic framework. Essentially, the basic point is that wherever there are two or more political parties, and they are aware that their legislative proposals are determined through bipartisan support, they are players in a political game with each other. We assume that Congressional members are rational economic agents who considered legislative bills and President's cabinet position nominees based on merits and qualifications; and that the objective of Congress and a WHO is to pass bipartisan legislations $(\boldsymbol{\theta})$.

To simplify this theoretic game between Congressional Democrats and Republicans, we let the action sets of both parties be: DEM (Support, Oppose) and REP (Support, Oppose). In addition, we let $\delta$ and $\beta$ represent the percentage of Democrats and Republicans who support a WHO and his party's legislative agenda, while (1- $\delta$ ) and (1- $\beta$ ) represent those who oppose. ${ }^{11}$ The other stakeholder in this game is the President who cannot vote on legislations before Congress, but can use his or her political capital to influence several legislations. ${ }^{12}$ In a bipartisan Congress, both DEM and REP tend to choose a strategy profile (Support, Support) in support of a WHO's legislative proposals with the payoffs of $(1,1)$; and when there is a bipartisan opposition, the action set (Oppose, Oppose) will yield the payoffs $(0,0) .{ }^{13}$ Similarly, in a partisan and polarized Congress where members vote on the basis of party affiliation, Republicans will choose (Support) when there is a WHO-REP and (Oppose) whenever there is a WHO-DEM. In contrast, Democrats will choose (Support) for a WHO-DEM and (Oppose) for a WHO-REP.

The payoff matrix for this political game in Table 4 shows four different payoffs. First, we consider (Support, Support $)>($ Oppose, Support or Support, Oppose) $>$ (Oppose, Oppose). Second, the strategy and payoff combinations [(Support, Support), $(1,1)]$ and $[($ Oppose, Oppose $),(0,0)]$ shown in the rectangle are both Nash equilibria, but (Support, Support) Pareto-dominates (Oppose, Oppose). ${ }^{14}$ Third, the circled (Support, Oppose) and (Oppose, Support) strategy profiles illustrate the tit-for-tat between Democrats and Republicans in a Congressional political game, which would continue to exacerbate political polarization for the foreseeable future when the opposition party discriminates against a WHO due many factors and/or based on partisan animosity. As a retaliatory measure given the propensity to discriminate, Democrats and Republicans as players in a political game will continue to alternate (Support, Oppose) with (Oppose, Support), which explained why more extremely

\footnotetext{
${ }^{10}$ As just one example of what we mean, consider Republicans' and Democrats' about-face on the "individual mandate" of the Affordable Care Act. Although Republicans (Democrats) opposed (supported) the idea of an "individual mandate" during the debate over the Affordable Care Act, they supported (opposed) it in the healthcare debate that occurred during the Clinton administration (see, e.g., Cooper 2012). As Klein (2012) reported, "The Republicans have made the individual mandate the element most likely to undo Obama's health-care law. The irony is that the Democrats adopted it in the first place because they thought that it would help them secure conservative support. It had, after all, been at the heart of Republican health-care reforms for two decades."

${ }^{11}$ The expected outcome for $R E P$ is $\beta[\delta+(1-\delta)]+(1-\beta)[0(\delta)+0(1-\delta)]=\beta$, and for $D E M$, the expected outcome is $\delta[\beta+$ $(1-\beta)]+(1-\delta)[0(\beta)+0(1-\beta)]=\delta$; therefore, any WHO or Congress would want $\delta=1$ and $\beta=1$.

12 Note that the party with a significant majority in Congress can pass bills without the support of the opposite party.

${ }^{13}$ This outcome $(0,0)$ can also happen when there is a particular legislative bill before Congress that the constituents from both parties oppose, and lawmakers from both parties fear losing their seats in Congress if they vote to support such legislation. In other words, there are instances when more Republicans and Democrats Oppose than Supporta WHO's legislative bill [that is, $(1-\delta)>\delta$ and $(1-\beta)>\beta$.

${ }^{14}$ Note that this (Support, Support) does not mean that every Democrat and Republican voted to pass the legislation: it simply means it passed by majority. Similarly, (Oppose, Oppose) means majority from both parties opposed.
} 
dogmatic Republicans and Democrats seek elections into Congress to continue with the policies of obstructionism and "conflict extension."

Table 4: The congressional game

Support $(\beta)$

Note: Authors chose the payoffs for illustrative purpose and not by a specific metric.

In the real world, political game between Democrats and Republicans is not a one-time game. It is repeated in every Congressional session, but resentment of a WHO by the opposition party now plays a major role in the outcomes in many legislative sessions. In Panel A of Figure 1, we show the expected annual outcomes of repeated political interactions in the next four or eight Congressional sessions now that the 2016 presidential election yielded a WHO-REP. We expect

REP (Support) and DEM (Oppose) to continue during the 115th Congress and beyond, thus fostering partisan obstructionism and political polarization. In Panel B, we project or show that if the 2020 or 2024 election outcome yields a WHO-DEM, we should expect DEM (Support) and REP (Oppose) to be the dominant strategies by both parties going forward. Under this framework, the Democrats-Republicans interactions can be considered as politically dogmatic strategy profiles used in infinitely-repeated games where the previous moves are common knowledge to both parties. The tit-for-tat interactions between Democrats and

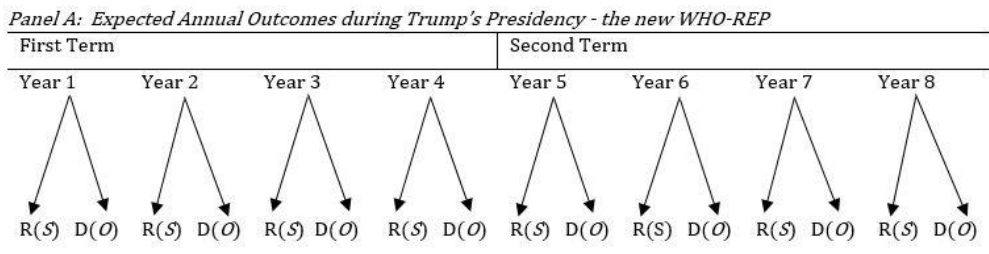

Panel B: Expected Annual Outcomes during the Presidency if the 2020 or 2024 Presidential Election Yields a WHO-DEM

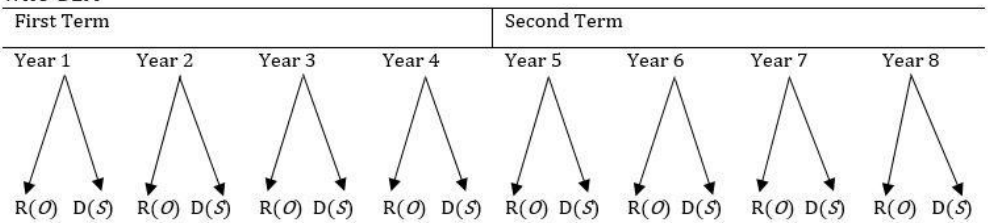

Figure 1: Expected annual legislative outcomes of congressional interactions in different presidential terms.

Note: $\mathrm{R}(\mathrm{S})$ and $\mathrm{D}(0)=\mathrm{REP}$ (Support) and DEM (Oppose), while $\mathrm{R}(0)$ and $\mathrm{D}(\mathrm{S})=\mathrm{REP}$ (Oppose) and DEM (Support).

Republicans will not yield a subgame-perfect Nash equilibrium. Since this game can be repeated infinite number of times in many Congressional sessions and a wide range of outcomes are possible as depicted in Figure 1, this is consistent with the Folk Theorem which tells us that this pattern of behavior by two political parties is irrational. 15 From the perspective of Folk Theorem, the dominant strategies adopted by both parties appeared to generate predictable pattern of behavior considered to be unreasonable.

It is noteworthy that the outcomes in Panel B reflected the outcomes experienced under the two-term tenure of Obama, and this lend credence to the Congressional productivity reported in Table 2, which showed Obama as the president had fewer laws enacted. Regrettably, the current Congressional environment of extremism and polarization would continue under the Trump's administration because Democrats are ready to reciprocate with aggressive oppositions and/or obstructionism. The Democrats will reciprocate not because of racial resentment of Trump, but on policy issues such as the repeal of the Affordable Care Act and the defunding of various social programs that Democrats support. Arguably, the victories recorded by Republicans in the past two mid-term and the 2016 presidential elections have bolstered their ideological positions, which could be interpreted as a strong indication that the American electorate supported Congressional Republicans with respect to their dominant strategy of Oppose. Given these electoral victories, one should not expect Republicans to switch from their dominant strategy whenever they are the opposition party; however, it is doubtful if the Democrats will achieve similar electoral victories if they adopt the same strategy of Oppose over the next four or eight years of a WHOREP.

\footnotetext{
15 See Rasmusen (2007) on Folk Theorem. This is the outcome of a dynamic repeated game in which there is no credible threat from either party, so Democrats and Republicans will not change their dominant strategies given a partisan and polarized Congress where it is not possible for DEM to punish REP and vice-versa, except to reciprocate.
} 
The main contention from this game is that the strategy to vote in opposition based on party affiliation became the dominant strategy ${ }^{16}$ during the two-term Obama's presidency because Republicans racially resented and discriminated against Obama as a WHO-DEM. Despite the enormous political capital that Obama gained from the two elections he won, he could not form workable coalitions with Congressional Republican leaders. Simply put, $s^{*}\left(s_{D E M}^{*}, s_{R E P}^{*}\right)^{17}$ for both DEM and REP was the best response to any strategy the other party might choose, even when such actions by the other party are considered to be wildly irrational and gender or racially discriminatory at best.

We summarize these outcomes algebraically as:

$$
\left.\theta\right|_{W H O-R E P} ^{W H O-D E M}=f(\delta D E M, \beta R E P, W H O P O L C A P), \quad \delta+\beta=1
$$

where $\beta R E P$ and $\delta D E M$ represent the percentage or number of Republicans and Democrats in Congress supporting a $W H O$ s legislative agenda, and WHOPOLCAP $(0 \geq W H O P O L C A P \leq 1)$ captures a WHO's political

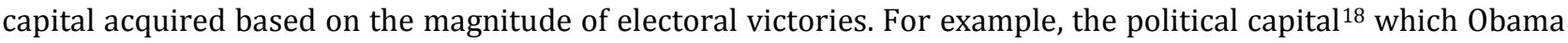
could have expended on Congressional Republicans for legislative support did not matter because Republicans harbored racial resentment and discriminated against him even when he proposed the same legislative bills that the Republicans once proposed and supported.

In other words, Obama experienced zero or negative ( WHOPOLCAP $\leq 0$ ) political capital during his presidency, which meant he had no political leverage over Congressional Republicans in passing legislative bills, thus "toxically pandemic political polarization", which pundits now analyze. The general consensus among these pundits is consistent with our political game analysis, which showed that Democrats chose Support with a payoff of 1 and Republicans chose Oppose with a payoff of 0 because of racial resentment and the perceived religious identity of Obama. With Trump's election as a new WHO-REP, we expect the Republicans to switch their dominant strategy from Oppose with a payoff 0 under Obama to Support with a payoff of 1 under Trump; and for Democrats to choose Oppose with a payoff as a retaliatory measure over the next four or eight years. In principle, we expect DEM and REP to alternate (Support, Oppose) with (Oppose, Support) in a tit-for-tat strategy profile in the foreseeable future.

The problem with the alternate strategy profile is that it will continue into the foreseeable future thus the values of $\beta$ and $\delta$ will be consistently equal to zero whenever there is a WHO-DEM or a WHO-REP; and this therefore means that major legislations will be passed or repealed by the party that controls Congress. For example, the passage of the Affordable Care Act ${ }^{19}$ (ACA or Obamacare) in 2010 occurred because the Democrats had the majority in Congress and controlled the White House (that is, $\delta D E M>\beta R E P$ ). With roles now reversed and Republicans control the new 115th Congress (that is, $\delta D E M<\beta R E P$ ) and the White House based on the 2016 election, there is an indication that Republicans will eventually succeed in their repeated attempts to repeal Obamacare as a way to end their racial resentment and discrimination against Obama.

Given the changing political landscape in the United States, it is safe to argue that any WHO identified to belong to certain groups (African-American, Hispanic-American, Jewish-American, Women) should expect relentless oppositions to legislative proposals, no matter how well-intended the proposals might be. Therefore, in a polarized Congress and the opposition party resents or discriminates against a WHO in retaliation, legislations would stall. Now, given the strong probability that the opposition party not in control of Congress may be prejudiced and thus may discriminate against a WHO, we use Becker's (1957) model of discrimination to show that this will exacerbate political polarization.

Many analysts have argued that elected Democrats and Republicans are extensions or signals of the polarized electorate, and that just as the resentment of Obama as a WHO-DEM during his eight-year presidency accentuated the obstructionist legislative actions by Congressional Republicans, they anticipate that Democrats' resentment of Trump (WHO-REP), on policy positions or issues, would contribute to more partisan political polarization $(R)$ in Congress throughout his tenure; and therefore, we express this in equation form as:

\footnotetext{
16 Nationwide, it was well known that the dominant strategy of the Republican Party since President Obama's inaugural was Oppose; therefore, one can predict that the Democrats will reciprocate with the same strategy with a WHO-REP.

17 We follow this simple methodology because any model or "statistical method is fundamentally sound if only it tells you things you already know" - see Ellenberg's (2001). "Growing Apart: The Mathematical Evidence for Congress' Growing Polarization" at www.slate.com/articles/life/do_the_math/2001/12/growing_apart.html.

18 For more on whether or not Obama's political capital matters, see Evan Katz (2016).

19 The Obamacare exemplifies the racial resentments of Obama harbored by Republicans. This was aptly captured in surveys by news reporters in which non-Congressional Republicans overwhelmingly supported the repeal of Obamacare instead of the Affordable Care Act (ACA); and they are puzzled when told that Obamacare is the ACA.
} 


$$
R=H\left[\Omega, d(\mathrm{DEM}+R E P), W H O\left(z_{t}+z_{c}\right)\right]
$$

where $\Omega$ is vector of the external and internal causal factors that studies have identified as contributing to extreme partisanship and political polarization [see Barber and McCarty (2013, pp. 23-35)], $d$ is Becker's coefficient of discrimination, and $W H O\left(z_{t}+z_{c}\right)$ is a breakdown of how a WHO expends his political capital, which we expressed earlier as WHOPOLCAP in equation (1). We let $z t$ represent the fraction of a WHO's political capital devoted to political reprisals, and $z c$ is the fraction devoted to policy formulations and implementations as well as the building coalitions with Congressional members. As before, $0 \geq W H O P O L C A P=W H O\left(z_{t}+z_{c}\right) \leq 1$.

Scholars have pointed out that the changes in the external and internal causal factors contributed to political polarization over the past 40 years; therefore $\frac{\partial R}{\partial \Omega}>0$ means that both Democrats and Republicans have contributed to political polarization. In addition, as shown in equation (2), we assert that when Democrats and/or Republicans discriminate against a WHO, based on gender and/or racial resentment, perceived religious affiliation, and divisive policy pronouncements or positions, partisan political polarization will increase. In other words, $\frac{\partial R}{\partial D E M}=\frac{\partial R}{\partial R E P}=d>0$ means that both Democrats and Republicans contribute to partisan political polarization when they discriminate against and/or disagree with the policy positions of a WHO. In addition, $\left.\frac{\partial R}{\partial W H O}\right|_{z_{c}=0}=z_{t}>0$ means that when a WHO utilizes his entire political capital on political reprisals against Congressional members, the public, the intelligence community, media, and other business organizations, the more we encounter "toxically pandemic political polarization," which could undermine the democratic principles that Americans cherish.

As we pointed out earlier, the objective of the United States Congress and any WHO is to maximize utility by passing many legislative bills into laws, and that these laws are enacted through bipartisan support. That is, Congress will maximize utility $(U)$ given as:

$$
U=\boldsymbol{\theta} G(R E P+D E M, W H O)-\beta R E P-\delta D E M-R)
$$

where $G$ is the legislative production function of Congress, while $\theta$ and $R$ are as defined earlier. Replacing $R$ in equation (3) with its determinants from equation (2) yields:

$$
U=\theta G\left[(R E P+D E M, W H O)-\beta R E P-\delta D E M-\Omega-d(\mathrm{DEM}+R E P)-W H O\left(z_{t}+z_{c}\right)\right]
$$

We have argued that when Democrats and Republicans are prejudiced and discriminate against a WHO based on racial resentment, $d>0$, but more importantly, they will act as if the legislative bills and major cabinet nominees put forward by a WHO have no merits, and are therefore not worthy of Congressional considerations and actions. They will vote on legislative bills only if a WHO's party controls Congress, which will nullify the racial resentment and discriminatory propensities of the opposition party ( $\delta-\beta>d$ for a WHO-DEM or $\beta-\delta>d$ for a WHO-REP). The first partial derivatives of the utility function with respect to $R E P, D E M$, and $W H O$ yield:

$$
\begin{gathered}
\theta G^{\prime}(R E P)-\beta-d=0 \\
\theta G^{\prime}(D E M)-\delta-d=0 \\
\theta G^{\prime}(W H O)-z_{t}-z_{c}=0
\end{gathered}
$$

The optimal number of legislative proposals passed in each Congress is determined by the solutions to equations (5) - (7). That is:

$$
\begin{aligned}
\theta G^{\prime}(R E P) & =\beta+d \\
\theta G^{\prime}(D E M) & =\delta+d \\
\theta G^{\prime}(W H O) & =z_{t}+z_{c}
\end{aligned}
$$

As we explained earlier, both parties depend on each other for legislative success despite the propensity to discriminate, and a WHO's political capital, which we express algebraically as:

$$
\begin{aligned}
& \left.\theta\right|_{R E P}\left(\beta, \delta, d, z_{t}, z_{c}\right) \\
& \left.\theta\right|_{D E M}\left(\beta, \delta, d, z_{t}, z_{c}\right) \\
& \left.\theta\right|_{W H O}\left(\beta, \delta, d, z_{t}, z_{c}\right)
\end{aligned}
$$


Interpretatively, equations (11) - (13) show that the desire or demand by both Democrats and Republicans to get legislations $(\theta)$ passed would depend on the support from both parties [DEM $(\delta)$ and $R E P(\beta)]$ and their retaliatory discrimination $(d)$ against a WHO whenever they become the opposition party. In essence, when $d=0$, Democrats and Republicans can always find ways to form coalitions in order to get bills passed in Congress; and when $d \neq 0$, political polarization will intensify and less bills will be passed into laws as each party retaliates. Furthermore, $\theta$ also depends on a WHO's involvement and investment in the legislative process by which we mean the amount of political capital, $z_{t}$, a WHO devoted to political reprisals versus $z_{c}$ devoted to policy formulations/implementations as well as forming coalitions with Congressional members.

Many political pundits attributed the increased polarization during Obama's presidency as indicative of his inability to work with Congressional Republicans who wanted him to fail from day one of his presidency; and this contributed in no small measures to the low Congressional productivity we reported in Table 3. In other words, Obama's presidency contributed to polarization and low productivity because he was unable to use his political capital to influence Congressional Republicans to support his policy positions, that is, $\left(\left.\frac{\partial R}{\partial W H O}\right|_{z_{1}+z_{c} \leq 0}>0\right)$.

\subsection{Economic consequences of political polarization}

In this section, we examine the economic consequences of political polarization from the Congressional and aggregate perspectives. In terms of the Congressional perspective, we provide a theoretical analysis of the effect on polarization on Congressional productivity which occurred in the least-polarized and the most-polarized Congress, today. To do this, we use a modified Cobb-Douglas production function, ${ }^{20}$ in which $R$ still denotes polarization and the assumption that legislators are partisans. We incorporate $R$ into the Congressional production function as:

$$
X=\theta K^{\lambda}(R L)^{1-\lambda}
$$

where $X$ is the total output of Congress, $\theta$ is the total factor Congressional productivity, $K$ is the level of capital required by Congress to perform its legislative duties, $L$ is the Congressional labor force, $R L$ is a measure of the polarized legislators, and $\lambda$ and $1-\lambda$ are the shares of input in the production function. Rewriting equation (14) yields:

$$
X=R^{1-\lambda} \theta K^{\lambda} L^{1-\lambda}
$$

Economic growth theory suggests that capital evolves over time through investment in new capital stock as old capital depreciates. And in this framework, we assume a constant fraction $(\alpha)$ of Congressional output is invested capital and that the rate depreciation or allowance for capital consumption is $\eta$. In order to express this equation in per Congressional member/worker terms, we divide both sides of equation (15) by $L$ to get the per worker production function as:

$$
x=R^{1-\lambda} \theta k^{\lambda}
$$

where $x=X / L$ and $k=K / L$. We express the polarized-state of Congressional output per worker as (see Appendix $B$ for complete derivation of $x$ ):

$$
\begin{gathered}
x=\left(R^{1-\lambda} \theta\right)^{\frac{1}{1-\lambda}}\left(\frac{\alpha}{\eta}\right)^{\frac{\lambda}{1-\lambda}} \\
\text { or } x=R \times\left[(\theta)^{\frac{1}{1-\lambda}}\left(\frac{\alpha}{\eta}\right)^{\frac{\lambda}{1-\lambda}}\right]
\end{gathered}
$$

Next, we use equation (17) to consider Congressional output growth rates in two periods of polarization on the assumption of holding the values of $\theta, \alpha$, and $\eta$ constant for both periods, but different degrees of polarization in Congress - least-polarized $(I)$ and most-polarized $(m)$. Rewriting equation (17) for both $I$ and $m$ periods in Congress and then expressing the ratio of polarized-state levels of Congressional output, we have:

\footnotetext{
20 The modified Cobb-Douglas production function follows the conventional methodology used in growth models in deriving steady-state levels of capital per worker $(k)$ and output per worker $(y)$. For the detailed derivations of steady-state, see David N. Weil's Economic Growth, Chapters 3 to 10. For our analysis, we denote Congressional output per worker as $x$ in polarizedstate, not steady-state. See the Appendix for appropriate derivations.
} 


$$
\frac{x_{m}}{x_{l}}=\frac{R_{m} \times\left[(\theta)^{\frac{1}{1-\lambda}}\left(\frac{\alpha}{\eta}\right)^{\frac{\lambda}{1-\lambda}}\right]}{R_{l} \times\left[(\theta)^{\frac{1}{1-\lambda}}\left(\frac{\alpha}{\eta}\right)^{\frac{\lambda}{1-\lambda}}\right]}=\frac{R_{m}}{R_{l}}
$$

Equation (18) says that the ratio of Congressional output per worker in the least-polarized and most-polarized steady-states will be equal to the ratio of polarization between both periods. For simplicity or clarity in exposition, let us assume that Congress was least-polarized during Reagan's two-term presidency, but most-polarized during Obama's two-term tenure. If one compares the ratio of Congressional output during these two presidencies reported in Table 3, then one can conclude that Congress during Obama's presidency was twice more-polarized, regardless of whether or not skeptics attribute this to the increasing technical complexities of the legislative processes.

An important component that will be affected by political polarization is the measure of total factor Congressional productivity, $\theta$. We assert that $\theta$ in the least-polarized and/or post-polarized Congress will depend on the ease or otherwise with which coalitions $(C)$ can be formed and the level of efficiency in both periods. Borrowing from Weil (2014), we define Congressional efficiency, $E$, as the effectiveness with which factors of production and coalitions are formed to produce or pass legislative bills into laws; therefore, we define $\theta$ as the product of $C$ and $E$ :

$$
\theta=C \times E
$$

Again, we rewrite equation (19) for both $l$ and $m$ periods in Congress and then express the ratio of the mostpolarized and the least-polarized Congress as:

$$
\frac{\theta_{m}}{\theta_{l}}=\frac{C_{m}}{C_{l}} \times \frac{E_{m}}{E_{l}}
$$

and that the level of efficiency $\left(E_{m}\right)$ in the most-polarized Congress is:

$$
E_{m}=\left(\frac{C_{l}}{C_{m}} \times \frac{\theta_{m}}{\theta_{l}}\right) \text { × } E_{l}
$$

Equation (21) says that the level efficiency in the most-polarized Congress is some fraction of the level of efficiency in the least-polarized Congress. Based on our theoretical construct, political polarization affects not only the level of Congressional productivity, it also affects Congress's ability to form coalitions and the efficiency required to pass meaningful legislations.

Next, we analyze the effects of political polarization on the aggregate economy in order to show its economic consequences. In doing so, we postulate an aggregate production function, which can be expressed as:

$$
Y=F(K, L, N, A ; R)
$$

where $Y$ is total aggregate output, $K$ is the level of capital or physical infrastructure capital, $L$ is labor or total employment, $N$ is natural resources, $A$ is technology or the total factor productivity, which is assumed to be constant, and $R$ is the measure of political polarization. According to Acemoglu (2009), technology "has no natural unit and $(A)$ is simply a shifter of the production function," which is assumed to be "free: it is publicly available as a nonexcludable, nonrival good" in the neoclassical or Solow growth model.

It is important to point out that various regulatory legislative bills in Congress affect the employment and utilization of $K, L$, and $N$. For example, legislative bills dealing with infrastructure capital, capital gains tax, comprehensive immigration (e.g. guest workers' program) and the minimum wage, Keystone XL pipeline, and fracking will affect $K, L$, and $N$, respectively. To show how political polarization affects these important factors of production, we examine two cases of $R$. In the first case, we assume $R \approx 0$ during the era in which there was bipartisanship in Congress (e.g. the O'Neill-Reagan era); and in the second case, we assume $R>>0$ over the past three or more decades of increased partisan animosity and political polarization, especially during the two-term tenure of Obama's presidency. We differentiate equation (22) for both cases of $R \approx 0$ and $R>>0$ to obtain: 


$$
\left.F_{K} \equiv \frac{\partial F(K, L, N, A)}{\partial K}\right|_{R \approx 0}>0,\left.F_{L} \equiv \frac{\partial F(K, L, N, A)}{\partial L}\right|_{R \approx 0}>0,\left.F_{N} \equiv \frac{\partial F(K, L, N, A)}{\partial N}\right|_{R \approx 0}>0
$$

and that

$$
\left.F_{K R} \equiv \frac{\partial^{2} F(K, L, N, A, R)}{\partial K \partial R}\right|_{R>0}<0,\left.F_{L R} \equiv \frac{\partial^{2} F(K, L, N, A, R)}{\partial L \partial R}\right|_{R>0}<0,\left.F_{N R} \equiv \frac{\partial^{2} F(K, L, N, A, R)}{\partial N \partial R}\right|_{R>0}<0 \text { (24). }
$$

Equation (24) shows that whenever Congress is extremely partisan and polarized as was the case in the past eight years because Congressional Republicans could not come to terms in order to vote on key legislations that pertained to $K, L$, and $N$ due to racial resentment and discrimination against Obama (a WHO-Democrat), and his inability to form a workable coalition with these Congressional Republicans, this had adverse effects on economic growth both in the short-run and the long-run. We expect $R$ to continue to affect the employment and utilization of $K, L$, and $N$ under Trump's presidency, if Republicans are not united, despite their control of Congress and the White House because partisan animosity will continue to inhibit compromise from many, if not all, Democrats, especially on pending regulatory legislative bills. In contrast to technology, $A$, which shifts the production function outward, political polarization, $R$, is simply a negative shifter of the Congressional production function.

\section{Results and Discussion and Lessons Learned}

The central idea of this paper is that presidential discrimination is another dimension for empirical investigation into the on-going scholarly debate about political polarization in Congress and the electorate. We highlight the basis of political polarization in a game-theoretic framework by showing that Democrats and Republicans as players in a political game may alternate (Support, Oppose) with (Oppose, Support) into the foreseeable future; and that the propensity to discriminate against a WHO based on gender or racial resentment, misperceived religious affiliation, and/or WHO's divisive policy pronouncements would exacerbate political polarization.

We further show that the level of legislative productivity, during the tenure of any WHO and Congress, depends on the support from both parties and their taste of discrimination against a WHO, and perhaps more importantly, in a WHO's political capital devoted to political reprisals versus policy formulations and implementations through the formation of viable coalitions with Congress. In addition, we also show that political polarization and discrimination against a WHO have adverse effects on important factors of production because legislative bills by Congress affect the employment as well as the utilization of these factors. In other words, when legislative bills stall, or are passed without bipartisan support, or are voted down due to political polarization and discrimination against a WHO, and a WHO's inability to work with Congress, these would adversely impact economic growth in both the short-run and the long-run.

There are several implications and some limitations with respect to our analysis. First, as more women and minorities continue to participate in the political-electoral process, and racial and gender resentment still persist at the Congressional level, the legislative productivity of the United States Congress will likely continue its decline. In other words, the election of female and minority presidents will substantially affect the scope and content of the bills that are enacted into laws in conjunction with the underlying technical complexity of the law. This could produce an even more dramatic shift in legislation, and depending on its nature, lead to an even steeper increase in polarization, which will affect the economy. Second, one of the limitations of our analysis is that even though it suggests that political polarization exacerbated by presidential discrimination or resentment will impede economic growth, our analysis does not identify the major economic sectors most vulnerable to this potentiality. Thus, the next thing for future research is to identify the policy and economic areas most at risk for discriminationbased declines in growth. One way to do so is to identify areas of policy disagreement among Republicans and Democrats, link them to different sectors of the economy, and model in a game-theoretic framework to examine the effects of different institutional arrangements and their attendant levels of polarization on growth in these sectors.

Third, another limitation of our analysis is that it does not consider the institutional differences between the House of Representatives and the Senate. Adding complexity to the game by explicitly modeling variations in the way presidential discrimination or resentment operates in the House and Senate may offer further insight into political polarization. Furthermore, we are cognizant of the fact that the elected officials, who represent the two political parties as the players in this game, are only a few of the actors that operate in the political system. Special interests groups, who can be considered as the outside referees with monetary rewards to both parties and/or players in these Congressional political games, are notorious for lobbying Congress and the Presidency, and allowing them to move in this game may add another complex layer of nuance to the relationship between presidential 
discrimination, political polarization, a WHO's policy positions or pronouncements, and changes in economic growth.

Earlier in this paper we asked some pertinent questions that centered on how to minimize polarization and how to curtail the entry of partisan extremists who foster "conflict extension." To address these questions, we conclude by making some practical policy recommendations, which in our opinion could minimize the extent of political polarization and the entry of partisan extremists if a WHO and the United States Congress are bold enough to adopt a new policy strategy: more diversity in presidential cabinet appointments using the win-loss product rule. ${ }^{21}$ This would require that cabinet appointments be filled by a certain number of qualified individuals from the opposite party based on the win-loss product rule margins in the popular and Electoral College votes. Even though past presidents have appointed one or two members of the opposite party to their cabinets, this symbolic inclusion is not sufficient to show a WHO's commitment to bridging the partisan division. Including more members from the opposite party, based on our proposed formula, may do much to minimize polarization and discrimination against the President.

With respect to the legislative branch, we assert that polarization can be reduced if Congress adopts the majorityminority product configuration by offering the minority party more meaningful opportunities to influence the legislative agenda. One such possibility would be to increase the power of ranking minority members on Congressional committees or revise House and Senate procedures so that minority members could chair of some Congressional committees based on our recommended majority-minority product configuration policy strategy. This measure may encourage both parties to find common grounds and the desire to return to forming meaningful coalitions on many legislative bills and issues.

As for what we learned from the outcomes of the 2016 presidential election, we saw that between the polarized electorate and money in politics, which studies identified as the two most important of the external causal factors, the former determined the outcome of the elections. When the general public distrusts lawmakers (or elected officials) from both parties and the electorate is extremely polarized, arguably money in politics does not matter; and this manifested itself in both the primaries and the general elections. For example, the candidate who raised the most money during the Republican primary was not their nominee for the general election. Similarly, the candidate who raised and spent the most money in the general election also lost, which meant that money in politics failed or could not to mitigate the extent of public mistrust of lawmakers and political polarization. Also, we learned that those who deviated and violated the standard political norms observed for decades did not suffer for doing so. For example, presidential candidates in the past touted the "political human capital" 22 they acquired at the local, state, and national levels of government as their main qualifying factor for the presidency. We learned from the outcome of the election that this implicit acquisition of "political human capital" does not matter in the past election cycle, perhaps because the extremely polarized and "angry" electorate appeared to challenge these traditional norms through their willingness to replace the implicit "political human capital" with "business human capital" or corporate experience; therefore, analysts should not be surprised to see an avalanche of political novices compete at the party primaries in the next presidential election cycle.

More importantly, we learned that the American democratic-political system is susceptible to foreign interference through the use of information technology. Given the era of globalization and the suspicion of foreign intervention in the outcome of the election, there is the possibility that if foreign policy pronouncements and positions create global uncertainty, political polarization in the United States could transform into international polarization, which could be an impediment to the formation of international alliances, and this could be globally unsettling.

Acknowledgement: The authors gracefully acknowledge the comments and suggestions of two anonymous referees and the Editorial Board. As usual, the authors are responsible for the errors and omissions.

\section{References}

Abramowitz, Alan I. 2010. The Disappearing Center: Engaged Citizens, Polarization, and American Democracy. New Haven, CT: Yale University Press.

\footnotetext{
${ }^{21}$ This recommended win-loss product rule or the majority-minority product configuration is different from the proportional representation practiced in many European countries such as Germany. This would not encourage the mushrooming of political parties that some skeptics tend to associate with proportional representation.

${ }^{22}$ It is important to point out that "political human capital" as explained above is an $e x$-ante factor, and this is different from political capital (with its core: democratic norms, voting, campaign activities, and contacting public officials), which is inherent in the public, and which politicians viewed as being acquired from their electoral victories or acquired through high favorability ratings with the electorate.
} 
Acemoglu, Daron. 2009. Introduction to Modern Economic Growth. Princeton, New Jersey: Princeton University Press.

Adler, E. Scott and John Wilkerson. Congressional Bills Project. http://congressionalbills.org.

Aldrich, John. 1995. Why Parties? The Origin and Transformation of Political Parties in America. University of Chicago Press. https://doi.org/10.7208/chicago/9780226012773.001.0001

Ansolabehere, Stephen, John M. de Figueiredo, and James M. Snyder. 2003. "Why is There so Little Money in U.S. Politics?" Journal of $\quad$ Economic $\quad$ Perspectives, $17(1):$ 105-130. https://doi.org/10.1257/089533003321164976

Ansolabehere, Stephen, Jonathan Rodden, and James M. Snyder. 2006. "Purple America." Journal of Economic Perspectives 20(2): 97-118. https://doi.org/10.1257/jep.20.2.97

Bafumi, Joseph, and Michael C. Herron. 2010. "Leapfrog Representation and Extremism: A Study of American Voters and Their Members in Congress." American Political Science Review 104(03): 519-542. https://doi.org/10.1017/S0003055410000316

Barber, Michael and Nolan McCarty. 2013. "Causes and Consequences of Polarization." In Negotiating Agreement in Politics, eds. Jane Mansbridge and Cathie Jo Martin. America Political Science Association

Barber, Michael. 2013. "Ideological Donors, Contribution Limits, and the Polarization of State Legislatures?" Typescript. Princeton, NJ: Princeton University.

Baron, David P. 1994. "Electoral Competition with Informed and Uniformed Voters." American Political Science Review 88(1): 33-47. https://doi.org/10.2307/2944880

Bartels, Larry. 2000. "Partisanship and Voting Behavior 1952-1996." American Journal of Political Science 44(1): 35-50. https://doi.org/10.2307/2669291

Bartels, Larry. 2008. Unequal Democracy: The Political Economy of the New Gilded Age. Princeton, NJ: Princeton University Press.

Becker, Gary S. 1957. The Economic of Discrimination. University of Chicago Press.

Bishop, Bill. 2009. The Big Sort: Why the Clustering of Like-Minded Americans Is Tearing Us Apart. New York: Mariner Books.

Bonica, Adam. 2013. "Ideology and Interests in the Political Marketplace." American Journal of Political Science 57(2): 294-311. https://doi.org/10.1111/ajps.12014

Bonilla-Silva, Eduardo. 2010. Racism without Racists: Color-Blind Racism and Racial Inequality in Contemporary America. 3rd edition. New York: Rowman and Littlefield.

Brewer, Mark, Mack Mariani, and Jeffrey M. Stonecash. 2002. Diverging Parties: Social Change, Realignment, and Party Polarization. Boulder, CO: Westview Press.

Bullock, Will, and Joshua D. Clinton. 2011. "More a Molehill than a Mountain: The Effects of the Blanket Primary on Elected Officials' Behavior from California." Journal of Politics 73(3): 915-930. https://doi.org/10.1017/S0022381611000557

Carsey, T. M., \& Layman, G. C. 2006. "Changing Sides or Changing Minds? Party Identification and Policy Preferences in the American Electorate," American Journal of Political Science, 50(2): 464-477. https://doi.org/10.1111/j.1540-5907.2006.00196.x

Carson, Jamie L., Michael H. Crespin, Charles J. Finocchiaro, and David W. Rohde. 2007. "Redistricting and Party Polarization in the US House of Representatives." American Politics Research 35(6): 878 -904. https://doi.org/10.1177/1532673X07304263

Clinton, Joshua D. 2006. "Representation in Congress: Constituents and Roll Calls in the 106th House." Journal of Politics 68(2): 397-409. https://doi.org/10.1111/j.1468-2508.2006.00415.x

CNN. 2009. "Carter Again Cites Racism as Factor in Obama's Treatment." CNN. 17 September

Cooper, Michael. 2012. "Conservatives Sowed Idea of Health Care Mandate, Only to Spurn it

Cox, Gary, and Mathew McCubbins. 2005. Setting the Agenda: Responsible Party Government in the U.S. House of Representatives. Cambridge University Press. https://doi.org/10.1017/CB09780511791123

Darity, Jr. William (1989), "What's Left of the Economics of Discrimination?" in William Darity, Jr., Editor of the Economics of Discrimination - International Library of Critical Writings in Economics series; two volume set by Edward Elgar Publishing, 1995.

DellaVigna, Stefano, and Ethan Kaplan. 2007. "The Fox News Effect: Media Bias and Voting." Quarterly Journal of Economics 122(3): 1187-1234. https://doi.org/10.1162/qjec.122.3.1187

Edwards, Mickey. 2012. The Parties versus the People: How to Turn Republicans and Democrats into Americans. Yale University Press.

Eilperin, Juliet. 2007. Fight Club Politics: How Partisanship Is Poisoning the House of Representatives. Lanham, MD: Rowman \& Littlefield.

Ellenberg, Jordan. 2001. "Growing Apart: The Mathematical Evidence for Congress' Growing Polarization" at www.slate.com/articles/life/do_the_math/2001/12/growing_apart.html.

Ensley, Michael J. 2009. "Individual Campaign Contributions and Candidate Ideology," Public Choice 138(1): 221238. https://doi.org/10.1007/s11127-008-9350-6 
Fiorina, Morris P. 2013. "Party Homogeneity and Contentious Politics," In Can We Talk? The Rise of Rude, Nasty, Stubborn Politics, Daniel M. Shea and Morris P. Fiorina eds. New York: Pearson: 142-153.

Fiorina, Morris P., and Samuel J. Abrams. 2008. "Political Polarization in the American Public." Annual Review Political Science 11: 563-588. https://doi.org/10.1146/annurev.polisci.11.053106.153836

Fiorina, Morris P., Samuel J. Abrams, and Jeremy Pope. 2005. Culture War? Myth of a Polarized America. Upper Saddle River, NJ: Pearson Education.

Garand, James C. 2010. "Income Inequality, Party Polarization, and Roll-Call Voting in the US Senate." Journal of Politics 72(04): 1109-1128. https://doi.org/10.1017/S0022381610000563

Gelman, Andrew. 2009. Red State, Blue State, Rich State, and Poor State: Why Americans Vote the Way They Do. Princeton, NJ: Princeton University Press. https://doi.org/10.1515/9781400832118

Gentzkow, Matthew, and Jesse M. Shapiro. 2006. "Media Bias and Reputation." Journal of Political Economy 114(2): 280-316. https://doi.org/10.1086/499414

Gerber, Alan, Dean Karlan, and Daniel Bergan. 2009. "Does the Media Matter? A Field Experiment Measuring the Effect of Newspapers on Voting Behavior and Political Opinions." American Economic Journal: Applied Economics 1(2): 35-52. https://doi.org/10.1257/app.1.2.35

Gilens, Martin. 2012. Affluence and Influence: Economic Inequality and Political Power in America. Princeton, NJ: Princeton University Press.

Gilmour, John. 1995. Strategic Disagreement: Stalemate in American Politics. University of Pittsburgh Press.

Groseclose, Timothy, and Nolan McCarty. 2001. "The Politics of Blame: Bargaining before an Audience." American Journal of Political Science 45(1): 100-119. https://doi.org/10.2307/2669362

Groseclose, Timothy, and Jeff Milyo. 2005. "A Measure of Media Bias." Quarterly Journal of Economics 120(4): 1191-1237. https://doi.org/10.1162/003355305775097542

Hacker, Jacob S., and Paul Pierson. 2006. Off Center: The Republican Revolution and the Erosion of American Democracy. New Haven, CT: Yale University Press.

Hall, Robert L., and Frank W. Wayman. 1990. "Buying Time: Moneyed Interests and the Mobilization of Bias in Congressional Committees." American Political Science Review 84(3): 797-820. https://doi.org/10.2307/1962767

Hare, Christopher and Keith T. Poole (2014), "The Polarization of Contemporary American Politics, Polity, 46(3): 411-430. https://doi.org/10.1057/pol.2014.10

Hare, Christopher, Nolan McCarty, Keith T. Poole, and Howard Rosenthal. 2012. "Polarization is Real (and Asymmetric)." Voteview Blog. 16 July 2016 http://voteview.com/blog/?p=494

Hirano, Shigeo, James M. Snyder, Jr., Stephen Ansolabehere, and John Mark Hansen. 2010. "Primary Elections and Partisan Polarization in U.S. Congressional Elections." Quarterly Journal of Political Science 5(2): 169-191. https://doi.org/10.1561/100.00008052

Huddy, Leonie and Stanley Feldman. 2009. "On Assessing the Political Effects of Racial Prejudice." Annual Review of Political Science 12: 423-447. https://doi.org/10.1146/annurev.polisci.11.062906.070752

Hughey, Matthew W. 2012. "Show Me Your Papers! Obama's Birth and the Whiteness of Belonging." Qualitative Sociology 35: 163-181. https://doi.org/10.1007/s11133-012-9224-6

James, David. 2013. "Lawmakers in Name Only? Congress Reaches Productivity Lows." National Public Radio. National Public Radio. 03 December 2013. Web. http://www.npr.org/blogs/itsallpolitics/2013/12/03/ 248565341/lawmakers-in-name-only-congress-reaches-productivity-lows.

Jacobson, Gary C. 1990. "The Effects of Campaign Spending in House Elections: New Evidence for Old Arguments." American Journal of Political Science 34(2): 334-362. https://doi.org/10.2307/2111450

Katz, Evan (2016), "Does Political Capital Matter?" Politics in Theory and Practice: Analyzing International Relations and American Politics. https://politicstheorypractice.wordpress.com/2016/04/06/doespolitical-capital-matter.

Kaufmann, Karen M., James G. Gimpel, and Adam H. Hoffman. 2003. "A Promise Fulfilled? Open Primaries and Representation." Journal of Politics 65(2): 457-476. https://doi.org/10.1111/1468-2508.t01-2-00009

Klein, Ezra. 2012. "Unpopular Mandate: Why Do Politicians Reverse Their Positions?" The New Yorker. 25 June 2012. http://www.newyorker.com/magazine/2012/06/25/unpopular-mandate.

Klinkner, Philip A. 2004. "Red and Blue Scare: The Continuing Diversity of the American Electoral Landscape." The Forum (2)2. https://doi.org/10.2202/1540-8884.1035

Laband, D. N. 1986. "Congressional Junketeering: Public Sector X-Inefficiency." Journal of Economics and Business 38: 131 - 140. https://doi.org/10.1016/0148-6195(86)90023-8

Ladewig, Jeffrey W. 2014. "Polity Symposium: Partisan Polarization and American Democracy," Polity, 46 (3): 407 410. https://doi.org/10.1057/pol.2014.16

Layman, Geoffrey, and Thomas Carsey. 2002. "Party Polarization and 'Conflict Extension' in the American Electorate." American Journal of Political Science 46(4):786-802. https://doi.org/10.2307/3088434

Layman, Geoffrey C., Thomas M. Carsey, John C. Green, Richard Herrera, and Rosalyn Cooperman. 2010. "Activists and Conflict Extension in American Party Politics." American Political Science Review 104(2): $324-346$. https://doi.org/10.1017/S000305541000016X 
Lee, Frances. 2009. Beyond Ideology: Politics, Principles, and Partisanship in the U.S. Senate. University of Chicago Press. https://doi.org/10.7208/chicago/9780226470771.001.0001

Lenz, Gabriel S. 2012. Follow the Leader: How Voters Respond to Politicians' Policies and Performance. University of Chicago Press. https://doi.org/10.7208/chicago/9780226472157.001.0001

Lessig, Lawrence. 2011. Republic, Lost: How Money Corrupts Congress-and a Plan to Stop It. New York: Twelve/Hachette Book Group.

Levendusky, Matthew. 2009. The Partisan Sort: How Liberals Became Democrats and Conservatives Became Republicans. University of Chicago Press. https://doi.org/10.7208/chicago/9780226473673.001.0001

Levendusky, Matthew S., Jeremy C. Pope, and Simon D. Jackman. 2008. "Measuring District-Level Partisanship with Implications for the Analysis of US Elections." Journal of Politics 70(3): 736-753. https://doi.org/10.1017/S0022381608080729

Mann, Thomas E., and Norman J. Ornstein. 2012. It's Even Worse Than It Looks: How the American Constitutional System Collided with the New Politics of Extremism. New York: Basic Books.

Masket, Seth, Boris Shor, Steven Rogers, and Nolan McCarty. 2013. "A Primary Cause of Partisanship? Nomination Systems and Legislator Ideology." Typescript. Princeton, NJ: Princeton University.

McCarty, Nolan, Keith T. Poole, and Howard Rosenthal. 1997. Income Redistribution and the Realignment of American Politics. Washington, DC: AEI Press.

McCarty, Nolan, Keith T. Poole, and Howard Rosenthal. 2001. "The Hunt for Party Discipline in Congress." American Political Science Review 95(3): 673-688. https://doi.org/10.1017/S0003055401003069

McCarty, Nolan, Keith T. Poole, and Howard Rosenthal. 2006. Polarized America: The Dance of Ideology and Unequal Riches. Cambridge, MA: The MIT Press.

McCarty, Nolan, Keith T. Poole, and Howard Rosenthal. 2009. "Does Gerrymandering Cause Polarization?" American Journal of Political Science 53(3): 666-680. https://doi.org/10.1111/j.1540-5907.2009.00393.x

McClosky, Herbert, Paul J. Hoffmann, and Rosemary O'Hara. 1960. "Issue Conflict and Consensus among Party Leaders and Followers." American Political Science Review 54(2): 406-427. https://doi.org/10.2307/1978302

Moon, Woojin. 2004. "Party Activists, Campaign Resources and Candidate Position Taking: Theory, Tests and Applications." British Journal of Political Science 34(4): 611-633. https://doi.org/10.1017/S0007123404000213

Petersen, R. Eric., Terrence L. Lisbeth, Mabel Gracias, and Parker H. Reynolds. 2010.

Piketty, Thomas, and Emmanuel Saez. 2003. "Income Inequality in the United States 1913-1998." Quarterly Journal of Economics 118(1): 1-39. https://doi.org/10.1162/00335530360535135

Poole, Keith T. 2007. "Changing Minds? Not in Congress!" Public Choice 131:435-451 https://doi.org/10.1007/s11127-006-9124-y

Prior, Markus. 2007. Post-Broadcast Democracy: How Media Choice Increases Inequality in Political Involvement and Polarizes Elections. New York: Cambridge University Press. https://doi.org/10.1017/CB09781139878425

Rasmusen, Eric. 2007. Games and Information: An Introduction to Game Theory, 4 Edition. Malden, MA: Blackwell Publishing Limited.

Roberts, Jason M. 2007. "The Statistical Analysis of Roll-Call Data: A Cautionary Tale." Legislative Studies Quarterly 32(3): 341-360. https://doi.org/10.3162/036298007781699636

Roberts, Jason M., and Steven S. Smith. 2003. "Procedural Contexts, Party Strategy, and Conditional Party Voting in the US House of Representatives." American Journal of Political Science 47(2): 305-317. https://doi.org/10.1111/1540-5907.00021

Rohde, David W. 1991. Parties and Leaders in the Postreform House. University of Chicago Press. https://doi.org/10.7208/chicago/9780226724058.001.0001

Rosenthal, Andrew. 2012. "Nobody Likes to Talk About It, but It's There." The New York Times. 3 January 2012. http://takingnote.blogs.nytimes.com

Sears, David and P.J. Henry. 2005. "Over Thirty Years Later: A Contemporary Look at Symbolic Racism and Its Critics." Advances in Experimental Social Psychology 37: 95-150. https://doi.org/10.1016/S00652601(05)37002-X

Shaw, Daron. 2012. "If Everyone Votes Their Party, Why Do Presidential Election Outcomes Vary So Much?" The Forum 3(1), Article 1. https://doi.org/10.1515/1540-8884.1519

Shor, Boris, and Nolan McCarty. 2011. "The Ideological Mapping of American Legislatures." American Political Science Review 105(3): 530-551. https://doi.org/10.1017/S0003055411000153

Sinclair, Barbara. 2006. Party Wars: Polarization and the Politics of National Policy Making. University of Oklahoma Press.

Smith, Richard A. 1995. "Interest Group Influence in the US Congress." Legislative Studies Quarterly 20(1): 89139. https://doi.org/10.2307/440151

Snyder, Jr., James M., and Tim Groseclose. 2000. "Estimating Party Influence in Congressional Roll-Call Voting." American Journal of Political Science 44(2): 193-211. https://doi.org/10.2307/2669305 
Snyder, Jr., James M., and David Stromberg. 2010. "Press Coverage and Political Accountability," Journal of Political Economy 118(2): 355-408. https://doi.org/10.1086/652903

Stiglitz, Joseph E. (1973), "The Approaches to the Economics of Discrimination," The American Economic Review, 63(2): 287-295.

Stone, Walt J., and Elizabeth N. Simas. 2010. "Candidate Valence and Ideological Positions in US House Elections." American Journal of Political Science 54(2): 371-388. https://doi.org/10.1111/j.1540-5907.2010.00436.x

Sunstein, Cass R. 2002. "The Law of Group Polarization." Journal of Political Philosophy 10: 175-195. https://doi.org/10.1111/1467-9760.00148

Theriault, Sean M. 2008a. Party Polarization in Congress. New York: Cambridge University Press. https://doi.org/10.1017/CB09780511790652

Theriault, Sean M. 2008b. "The Procedurally Polarized Congress." Annual Meeting of the American Political Science Association, Boston, MA.

Tope, Daniel, Justin T. Pickett, Ryon J. Cobb, and Jonathan Dirlam. 2014. "Othering Obama: Racial Attitudes and Dubious Beliefs about the Nation's First Black President." Sociological Perspective, 57(4): 450-469. https://doi.org/10.1177/0731121414536140

Tufte, Edward R. 1973. "The Relationship between Seats and Votes in Two-Party Systems." American Political Science Review 67(2): 540-554. https://doi.org/10.2307/1958782

Weil, David N. 2013. Economic Growth, Addison-Wesley/Pearson Publisher.

Zoellick, R. B. 1999. "Congress and the Making of U.S. Foreign Policy." Survival 41: 20-41. https://doi.org/10.1080/713660133

\section{APPENDIX A: Derivation of polarized-state $k$ and $x$}

To derive the polarized-state Congressional output per worker, it is assumed that Congress' gross investment ( $I$ ) is the sum of its net addition to capital stock $(\Delta K)$ plus depreciation $(D)$, which can be expressed algebraically as:

and

$$
\begin{gathered}
I=\Delta K+D \\
\Delta K=I-\mathrm{D} .
\end{gathered}
$$

Dividing both sides by $L$ yields:

$$
\Delta k=i-d,
$$

where $\Delta k=\Delta K / L, i=I / L$, and $d=D / L$. For $i$, economic growth theory suggests that a constant fraction, $\alpha$, is invested every period/year, therefore we have: $\alpha x$

For depreciation, $d$, economic growth theory also suggests that a constant fraction, $\eta$, of capital stock depreciates every period, therefore we have: $\eta k$, (where $k=K / L$ ) and substituting these values ( $\alpha x$ and $\eta k$ ) into $\Delta k=i-d$ above to get: $\Delta k=\alpha x-\eta k$. From equation (16) in the text, $x=R^{1-\lambda} \theta k^{\lambda}$, and then substitute this value into the equation above to get: $\quad \Delta k=\alpha\left(R^{1-\lambda} \theta k^{\lambda}\right)-\eta k$. Now, to find the polarized-state value of $k$, we set $\Delta k=0$, thus: $\quad 0=\alpha\left(R^{1-\lambda} \theta k^{\lambda}\right)-\eta k$, that is: $\alpha\left(R^{1-\lambda} \theta k^{\lambda}\right)=\eta k$ and the polarized-state value of $k$ is: $k=\left(R^{1-\lambda} \theta \frac{\alpha}{\eta}\right)^{\frac{1}{1-\lambda}}$, and then we substitute this into: $x=R^{1-\lambda} \theta k^{\lambda}$ to yield equation (17) as:

$$
x=\left(R^{1-\lambda} \theta\right)^{\frac{1}{1-\lambda}}\left(\frac{\alpha}{\eta}\right)^{\frac{\lambda}{1-\lambda}}
$$

or $x=R \times\left[(\theta)^{\frac{1}{1-\lambda}}\left(\frac{\alpha}{\eta}\right)^{\frac{\lambda}{1-\lambda}}\right]$ 